\title{
短距離秩序散乱理論を用いた $\mathrm{Si}(111)$ -
}

\section{$(\sqrt{3} \times \sqrt{3}) \mathrm{Ag} 3 \mathrm{~d}$ 準位の角度分解 XPS の研究*}

\author{
細谷 守男**. 藤川 高志**
}

（受付1989年11月30日，掲載決定1990年 1 月 6 日）

The Sutudy of Si $(111)-(\sqrt{3} \times \sqrt{3})$ Ag Surface Structure by Means of Ag 3d Angle-Resolved XPS: Application of Short-Range-Order Theory

Morio HOSOYA** and Takashi FUJIKAWA**

(Faculty of Engineering, Yokohama National University, Hodogaya, Yokohama 240)

(Received November 30, 1989, Accepted January 6, 1990)

\section{1. 序}

近年, 表面原子の深い内殼準位からの角度分解 X 線 光電子スペクトル（ARXPS）が表面構造の解析手段と して有効であることが，いくつかの研究で報告されてい る $^{1,10)}$. 本研究では我々が開発した短距離秩序散乱理 論 $^{2 \sim 4)}$ を用いて, 近年盛んに議論されている $\mathrm{Si}(111)-$ $(\sqrt{3} \times \sqrt{3}) \mathrm{Ag}$ 表面（以下 $\sqrt{3}$ 表面）の局所構造を，この 系で得られた Ag 3d ARXPSから解析した. 今までにこ の表面に対して測定された総ての実験事実を矛盾なく説 明できるモデルは提唱されていない．しかしこの系の表 面の局所構造を考える上で重要な 3 つの事実が，他の研 究から得られている.(1)この表面で得られる LEED ハ ターンは $\sqrt{3} \times \sqrt{3}$ の周期性を示す ${ }^{1,15)}$. (2) STM の画像は 八ニカム状に分布している表面最上層のポテンシャルの 存在を示す $6,8,13,14)$.このことから, 最上層に存在する原 子, または原子団がハニカム状に位直していると考えら れる。(3) SEXAFS から，最近接 $\mathrm{Si}-\mathrm{Ag}$ 原子間距離が $2.48 \pm 0.05 \AA$ と求められた ${ }^{5)}$. 以上の 3 点に対して, $\sqrt{3}$ 表面で議論すべき重要な点は次の 2 点である。(1) $\mathrm{Ag}$ 原子の被覆率. Hanbücken らはマイクロ・プローブ ・オージェ電子スペクトルから局所的な Ag の被覆率を 約 $2 / 3$ ML と報告している11). これに対して河野らは同 様の解析手段で約 $1 \mathrm{ML}$ と報告している10)。 また，

\footnotetext{
* 平成元年10月26日 第30回真空に関する連合講演会で講演（26P-9）

** 横浜国立大学工学部（干240 横浜市保土ヶ谷区常盤台156）
}

Copel らも ISS から被覆率を約 $1 \mathrm{ML}$ と報告している7) このように $\sqrt{3}$ 表面の被覆率は $2 / 3 \mathrm{ML}, 1 \mathrm{ML}$ のどちら か判っていない. (2)第 $1 \mathrm{Si}$ 層に対する $\mathrm{Ag}$ 層の位置.

Table 1 から判るように, Ag 層が第 $1 \mathrm{Si}$ 層の上に存在 しているのか, それとも第 $1 \mathrm{Si}$ 層の下に埋まっているの か判っていない. 本研究では以上の点を考慮して河野ら によって測定された Ag 3d 準位の ARXPSを解析し, $\sqrt{3}$ 表面の局所構造を検討した.

\section{2. 計算方法}

X 線の吸収によって内殼から放出された光電子は, 光電子波として伝播していく，光電子波は伝播の途中で 周辺の原子に散乱され様々な散乱過程を持つ波束として 検出器に到達する. この時, 散乱過程の異なる光電子波 に位相差が生じ，干渉を起こす．観測する方向を変える と散乱過程が異なるので干渉の起き方も異なってくる. 従って, 小さな立体角を持った検出器で測定すると角度 に依存した強度を持つスペクトル，つまり ARXPSが 検出される．以上の性質を利用して，実測スペクトルと あるモデルを仮定して計算したスペクトルを比較するこ とにより, 表面の局所構造を原子のスケールで決定する ことが可能となる.

従来のXPSの解析には励起の起こる中心原子から $\mathrm{s}$ 波の光電子波が放出されるという近似をよく用いる が1,10)，ここではそれを次のよ5に改良している ${ }^{2 \sim 4)}$. 一つは, 双極子選択則に従ってェミッターから放出され 
Table 1 Models for the $\operatorname{Si}(111)-(\sqrt{3} \times \sqrt{3})$ Ag surface

\begin{tabular}{lllc}
\hline \multicolumn{1}{c}{ Model } & \multicolumn{1}{c}{ 1st layer } & \multicolumn{1}{c}{ 2nd layer } & Ref. \\
\hline Embedded Ag Honeycomb Model & $\mathrm{Si}(1 \mathrm{ML})$ & $\mathrm{Ag}(2 / 3 \mathrm{ML})$ & 5 \\
Ag Honeycomb Model ${ }^{\mathrm{a})}$ & $\mathrm{Ag}(2 / 3 \mathrm{ML})$ & $\mathrm{Si}(1 \mathrm{ML})$ & 6 \\
Embedded Ag trimer Model & $\mathrm{Si}(2 / 3 \mathrm{ML})$ & $\mathrm{Ag}(1 \mathrm{ML})$ & \\
Ag Trimer Model ${ }^{\mathrm{b}}$ & $\mathrm{Ag}(1 \mathrm{ML})$ & $\mathrm{Si}(2 / 3 \mathrm{ML})$ & 7 \\
SAV (Silicon Adatom-Vacancy) Model & $\mathrm{Si}(2 / 3 \mathrm{ML})$ & $\mathrm{Ag}(1 \mathrm{ML})$ & 7,8 \\
Honeycomb-Si HCT Model & $\mathrm{Si}(2 / 3 \mathrm{ML})$ & $\mathrm{Ag}(1 \mathrm{ML})$ & 8,9 \\
HCT (Honeycombly Chained Triangle) Model & $\mathrm{Ag}(1 \mathrm{ML})$ & $\mathrm{Si}(1 \mathrm{ML})$ & 10 \\
Q-H (Quasi-Honeycomb) Model & $\mathrm{Ag}(2 / 3 \mathrm{ML})$ & $\mathrm{Ag}(1 / 3 \mathrm{ML})$ & \\
\hline
\end{tabular}

a) The Ag honeycomb model is obtained by exchanging the 1st Si layer and the Ag layer of the embedded Ag honeycomb model.

b) The Ag trimer model is obtained by exchanging the 1st Si layer and the Ag layer of the embedded Ag trimer model.

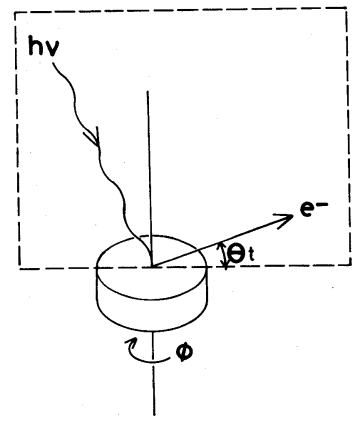

Fig. 1 Schematic illustration of the experimental geometry. The experiment is carried out by rotating the sample about the normal axis to the sample surface. The incident angle of the $x$-ray and the takeoff angle of the photolectron $\theta \mathrm{t}$ are fixed through a experiment. The photoelectron intensity is, hence, a function of only azimuthal angel $\phi^{1)}$. The incident $x$ rays, the detected photoelectron beams and the rotation axis are in the same plan shown by the broken line.

る光電子波の対称性を正しく考虑している点である．た とえば，3d 軌道から励起された光電子波は，双極子選 択則により， $\mathrm{p}$ 及び $\mathrm{f}$ 対称性を持つ。 もう一つは，入射 $\mathrm{X}$ 線の偏光, 非偏光の状態を考慮している点である. 実験装置が同じ幾何配置をしても，入射 X 線の状態に よってスペクトルの構造は違って来る. 従って, 入射 $\mathrm{X}$ 線の状態を考慮することも実測スペクトルを正確に 再現する上で重要である。本研究では測定条件に従い非 偏光の状態で計算を行った.

Fig. 1 に河野らによって行われたARXPS の測定に対 する実験の幾何配置を示す ${ }^{1)}$ 。そこでは，X 線の入射角 と光電子の検出角 $\left(\boldsymbol{\theta}_{\mathrm{t}}\right)$ を固定し, 試料表面に垂直な軸

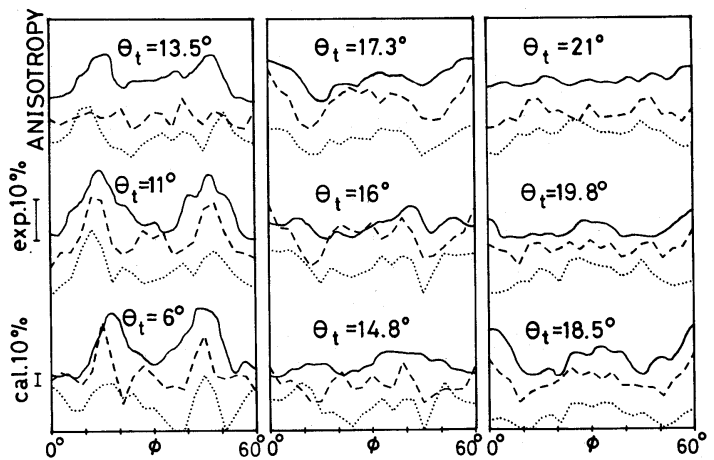

Fig. 2 Diffraction patterns of the Ag 3d ARXPS from the $\mathrm{Si}(111)-(\sqrt{3} \times \sqrt{3}) \mathrm{Ag}$ surface. This figure shows the anisotropy of the diffraction patterns. The solid lines shows the experimental diffraction patterns, both dashed (Q-H model) and the broken (HCT model) lines show the theoretical ones. In this figure the scale of the experimental data are extended by three times relative to those of theoretical ones.

を回転軸として試料を回転させることで，方位角 $(\phi)$ に依存したスペクトルが測定されている．以上の条件を 考虑し，原子間の光電子波の伝播を平面波で近似した 1 回散乱クラスターモデルでスペクトルの計算を行い，更 に 2 回散乱の効果も検討した。

計算されたスペクトルは異方性,

$$
\delta I=\frac{I(\phi)-I_{\min }}{I_{\max }} \times 100(\%)
$$

として処理され，同様に処理された実験スペクトルと比 較された. 


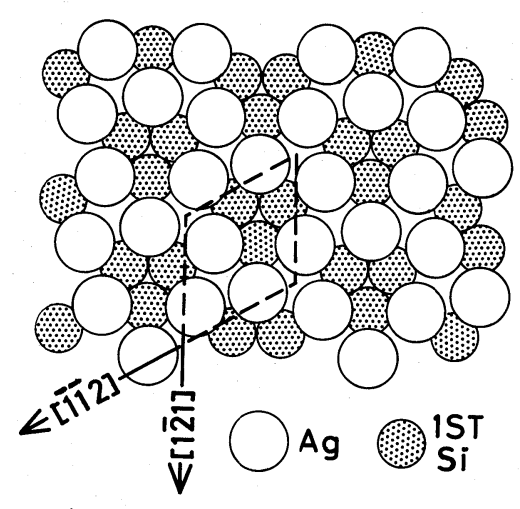

(a) TOP VIEW

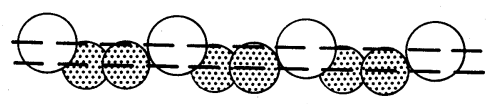

(b) SIDE VIEW

Fig. 3 Schematic representation of the HCT model for the $\mathrm{Si}(111)-(\sqrt{3} \times \sqrt{3}) \mathrm{Ag}$ surface used in this work, where (a) $[(b)]$ shows the top [side] view. The open and the shaded circles the $\mathrm{Ag}$ and the $\mathrm{Si}$ atoms, respectively. The $\sqrt{3} \times \sqrt{3}$ unit cell is shown by the rhombus with dashed line. The three nearest $\mathrm{Ag}$ atoms compose a Ag trimer. The center points of the Ag trimers from honeycomb framework.

\section{3. 結果及び考察}

最初に $\mathrm{Ag}$ 層の上飞第 $1 \mathrm{Si}$ 層が存在する EMBEDDED $\mathrm{Ag}$ HONEYCOMB モデル5), EMBEDDED Ag TRIMER モデル6), SAV (SILICON ADATOM-VACANCY) モデル7), HONEYCOMB-Si HCT モデル7,8) の 4 つのモデルについて計算を行った。 その結果，これらの モデルから得られたスペクトルは以下のような挙動を示 すために，不適当であることが判った． $\theta_{\mathrm{t}}$ が小さい場合 のスペクトルではピーク位置が一致しないか，たとえピ 一ク位置が一致してもピークの相対的な異方性が大きく 異なった。 $\theta_{\mathrm{t}}$ が大きくなると，ピーク位置が，一致しな いばかりでなく，Fig. 2 の実線で示された実測スペクト ルで見られる $\theta_{\mathrm{t}}$ の増加に供なった異方性の減少を再現 せず，異方性の大きな構造が現れた。これは $\mathrm{Si}$ 原子が エミッターである $\mathrm{Ag}$ 原子より上に存在するために， $\theta_{\mathrm{t}}$ が大きな場合でも Si 原子の前方散乱が強く影響してい る為だと考兄られる．以上の結果から我々の計算では $\mathrm{Si}$ 原子が Ag 原子の上存在するモデルは否定される. Copel らはISS で, 方位角を固定し, 散乱角（本研究の

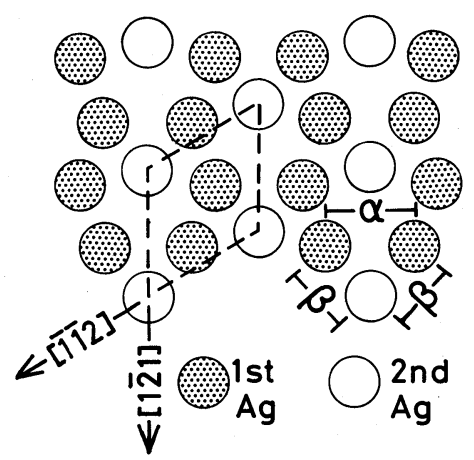

(a) TOP VIEW

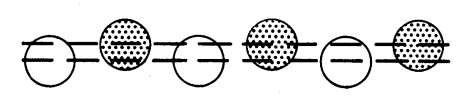

(b) SIDE VIEW

Fig. 4 Schematic representation of the QuasiHoneycomb model for the $\mathrm{Si}(111)-(\sqrt{3} \times \sqrt{3}) \mathrm{Ag}$ surfaee used in this work, where (a) [(b)] shows the top [side] view. The Ag atoms from two layers (see (b)). The shaded and the open circles represent $\mathrm{Ag}$ atoms in the 1st and the 2nd layer, respectively. The $\sqrt{3} \times \sqrt{3}$ unit cell is shown by the rhombus with deshed line. The structure is determined uniquely with the structural parmeters $\alpha, \beta$ and the distance between two layer. This model does not have 3-fold symmetry.

$\theta_{\mathrm{t}}$ に相当する）に依存した $\mathrm{Ag}$ 後方散乱スペクトルを観 測し, 散乱角が大きい場合に構造の乏しいスペクトルを 観測したと報告している7)。彼らはISS の結果から Ag 原子の上に Si 原子が存在するモデル (HONEYCOMBSi HCT モデル，SAVモデル）を提唱しているが，大 きな散乱角で構造の乏しいISS スペクトルはSi 原子が $\mathrm{Ag}$ 原子の上に存在しないことを示しているとも考元ら れる.

以上を考虑して, 次に我々は $\mathrm{Ag}$ 原子が $\mathrm{Si}$ 原子の上 に存在しているモデルを検討した。 まず，Ag HONEYCOMB モデル, Ag TRIMER モデルを計算したが，こ れらのモデルは実測スペクトルをうまく再現しなかっ た.これらに対して, HCT モデル8,9), Q-H (QUASIHONEYCOMB) モデル10) は他のモデルに比べてよい一 致を示した（Fig. 2). HCT モデル（Fig. 2, 破線）で は, $\theta_{\mathrm{t}}$ が $13.5^{\circ}$ から $16^{\circ}$ の 3 つ計算スペクトルで実測ス ペクトルに見られないピークがあるが，他は実測スペク トルを再現している。 また $\theta_{\mathrm{t}}$ の増大に伴らピークの構 造の減少を再現している. Fig. 3 に示された構造を持つ このモデルでは, 最上層に存在する 1 つの $\mathrm{Ag}$ 原子が, 
最近接する 4 つの $\mathrm{Ag}$ 原子と 2 つのトリマを作り，各 トリマーの中心がハニカムを作っていることが判る.こ の為, Ag 原子は局所的に崩れたハニカム構造を持ち, この Ag 原子の分布は STM の画像6,8,13,14) と矛盾しない. また， $\mathrm{Ag}$ 層のすぐ下に存在する $\mathrm{Si}$ 原子は， $\mathrm{Ag}$ 原子に 押されて互いに接近し，Siトリマーを作る。我々の解 析で得られた $\mathrm{Ag}-\mathrm{Si}$ の最近接原子間距離は2.29〜2.49 ̊ で,この值はSEXAFS の結果 $(2.48 \pm 0.04 \AA)^{5)}$ と矛盾 しない。また, 我々の解析では $\mathrm{Ag}$ 層と $\mathrm{Si}$ 層の間の層 間距離は $0.3 \AA$ となった. $\mathrm{Ag}-\mathrm{Ag}$ の最近接原子間距離は $3.42 \sim 3.49 \AA$ で, 我々の值は Sumitomo らの ICISS の結 果 $\left(\mathrm{Ag}-\mathrm{Ag}\right.$ は3.5 ̊ ${ }^{12)}$ と一致する. 更に, 第 $1 \mathrm{Si}$ 層の $\mathrm{Si}-\mathrm{Si}$ 最近接原子間距離は2.28〜2.63 $\mathrm{A}$ (バルクの $\mathrm{Si}-\mathrm{Si}$ 原子間距離は $2.35 \AA$ ) となった。我々の結果は $\mathrm{Ag}$ 層と $\mathrm{Si}$ 層の層距離を除いて Vlieg らが X 線回折の結果から 導いたモデル8)と良く似ている.

Q-H (QUASI-HONEYCOMB) モデル (Fig. 2, 点 線）では， $\theta_{\mathrm{t}}=14.8^{\circ}$ の計算スペクトルを除いて実測ス ペクトルを再現している．また， $\theta_{\mathrm{t}}$ の増加に伴う異方性 の構造の減少も再現している：このモデルの構造は Fig. 4 に示してある. 今回の解析では Si 原子の位置は 決定できなかった，真上から見る（Fig. 4(a)）と $3 つ$ の Ag 原子が作る 2 等辺三角形が $\sqrt{3} \times \sqrt{3}$ の周期性を持 って存在している. Ag 原子は垂直方向に昰んでおり, 我々の解析では第 $1 \mathrm{Ag}$ 層と第 $2 \mathrm{Ag}$ 層の層間距離は 0.3 ̊であった。第 $1 \mathrm{Ag}$ 層の $\mathrm{Ag}$ 原子は崩れたハニカム構造 を取る.これはSTMの画像が歪んだ八ニカム構造を示 していると言う Demuth らの報告16) と一致する. Fig. 4 にある構造パラメータは, 我々の解析では $\alpha=4.6 \AA$, $\beta=3.0 \sim 3.2 \AA$ となり河野らの結果(10) とよく似ている.

実測スペクトルが 3 回対称を持つことに反して, モデル は 3 回対称軸を持たない. 従って, Fig. 4 のように $\mathrm{Ag}$

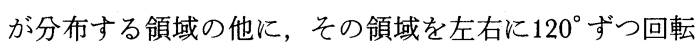
させて出来る 2 つの領域も同時に存在し, これら 3 つの 領域がランダムで均等に分布していると考えられる.

本研究ではこれら2つのモデル（Q-H モデル， HCT モデル) のらちどちらが現実に近いのかを結論付 けることはできなかった。しかし，以上の結果から， $\sqrt{3}$ 表面では $1 \mathrm{ML}$ の $\mathrm{Ag}$ 原子が局所的に崩れたハニカム 構造を持って表面最上層に存在していることが予想され る. 更に各モデルで 2 回散乱の効果を取り入れて計算を 行ったが，スペクトルに大きな違いは見られなかった． また，計算スペクトルの異方性のスケールは, Fig. 2 に 示されている通り実験スペクトルの $1 / 3$ 倍に取らなけれ
ばならなかった、計算スペクトルの異方性のスケールが 実測スペクトルのスケールよりも小さくなる傾向は他の 研究でも見られる1,8). これは弾性散乱に働く光学ポテ ンシャル17), 球面波の効果など, 計算では考慮していな い様々な効果が原因と考えられる. 今後はこれらの効果 を取り入れることによって, 最終的な構造の決定を行ら 予定である.

\section{5. よ め}

解析の結果から, HCT モデルと Q-H モデルの $2 つ$ のモデルが実測スペクトルを再現した. 従って $\sqrt{3}$ 表面 は $1 \mathrm{ML}$ の $\mathrm{Ag}$ 原子が局所的に崩れたハニカム構造を持 って最上層に存在していることが予想される.

\section{謝辞}

本研究では東北大学理学部の河野助教授に有益な助言 を頂きましたことに，ここで深くお礼を申し上げます。

\section{[文献〕}

1) S. Kono, K. Higashiyama and T. Sagawa: Surf. Sci. 165 (1986) 21

2) T. Fujikawa: J. Phys. Soc. Jpn. 50 (1981) 1321

3) T. Fujikawa: J. Phys. Soc. Jpn. 51 (1982) 251

4) T. Fujikawa: J. Phys. Soc. Jpn. 54 (1985) 2747

5) J. Stöhr and R. Jaeger: Surf. Sci. 134 (1985) 813

6) E. J. van Loenen, J. E. Demuth, R. M. Tromp and R. J. Hamers: Phys. Rev. Lett. 58 (1987) 373

7) M. Copel and R. M. Tromp: Phys. Rev. B39 (1989) 12688

8) E. Vlieg, A. W. van der Gon, J. F. van der Veen, J. E. MacDonald and C. Norris: Surf. Sci. 209 (1989) 100

9) T. Takahashi, S. Nakatani and N. Okamoto; Jpn. J. Appl. Phys. 27 (1988) L753

10) S. Kono, T. Abukawa and N. Nakamura; Jpn. J. Appl. Phys. 28 (1989) L1278

11) M. Hanbücken, M. Futamoto amd J. A. Venables: Surf. Sci. 147 (1982) 433

12) K. Sumitomo, K Tanaka, Y. Izawa, I. Katayama, F. Shoji, K. Oura and T. Hanawa: Appl. Surf. Sci. in press

13) R. J. Wilson and S, Chiang: Phys. Rev. Lett. 58 (1987) 369

14) R. J. Wilson and S, Chiang: Phys. Rev. Lett. 59 (1987) 2329

15) G. Le Lay: Surf. Sci. 132 (1983) 169

16) J. E. Demuth, E. J. Von Lenen, R. M. Tromp and J. Hamers: J. Vac. Sci \& Technol. B6 (1988) 18

17) T. Fujikawa and L. Hedin: Phys. Rev. B40 (1989) 11507 